\title{
Scheduled Study Activity Date and Time
}

National Cancer Institute

\section{Source}

National Cancer Institute. Scheduled Study Activity Date and Time. NCI Thesaurus. Code C71158.

An expression of both a date and time when a particular study activity assigned to be performed. 